\title{
Resveratrol-mediated cleavage of amyloid beta(1-42) peptide: potential relevance to Alzheimer's disease
}

DOI:

10.1016/j.neurobiolaging.2020.04.012

\section{Document Version}

Accepted author manuscript

Link to publication record in Manchester Research Explorer

\section{Citation for published version (APA):}

Al-Edresi, S., Alsalahat, I., Freeman, S., Aojula, H., \& Penny, J. (2020). Resveratrol-mediated cleavage of amyloid beta(1-42) peptide: potential relevance to Alzheimer's disease: potential relevance to Alzheimer's disease.

Neurobiology of Ageing, 94(24), 24-33. https://doi.org/10.1016/j.neurobiolaging.2020.04.012

\section{Published in:}

Neurobiology of Ageing

\section{Citing this paper}

Please note that where the full-text provided on Manchester Research Explorer is the Author Accepted Manuscript or Proof version this may differ from the final Published version. If citing, it is advised that you check and use the publisher's definitive version.

\section{General rights}

Copyright and moral rights for the publications made accessible in the Research Explorer are retained by the authors and/or other copyright owners and it is a condition of accessing publications that users recognise and abide by the legal requirements associated with these rights.

\section{Takedown policy}

If you believe that this document breaches copyright please refer to the University of Manchester's Takedown Procedures [http://man.ac.uk/04Y6Bo] or contact uml.scholarlycommunications@manchester.ac.uk providing relevant details, so we can investigate your claim.

\section{OPEN ACCESS}




\title{
Resveratrol-mediated cleavage of amyloid $\beta_{1-42}$ peptide; potential relevance to
}

\section{Alzheimer's disease}

\author{
Sarmad Al-Edresi ${ }^{1,2,3}$, Izzeddin Alsalahat ${ }^{1}$, Sally Freeman ${ }^{1}$, Harmesh Aojula ${ }^{1}$, Jeffrey Penny ${ }^{1,3}$ \\ ${ }^{1}$ Division of Pharmacy \& Optometry, School of Health Sciences, Faculty of Biology, Medicine \& Health, \\ University of Manchester, Manchester, M13 9PT, UK \\ ${ }^{2}$ Faculty of Pharmacy, University of Kufa, Najaf, Iraq \\ ${ }^{3}$ Joint Corresponding author
}

\begin{abstract}
Aggregation of amyloid $\beta_{1-42}\left(\mathrm{~A} \beta_{1-42}\right)$ peptide within the brain is considered one of the main causes of the neuropathological changes associated with Alzheimer's disease (AD). Resveratrol is a well-known antioxidant but has also been reported to bind to $A \beta_{1-42}$ peptide, thereby reducing aggregation. However, little is known of the precise mechanism by which resveratrol reduces $A \beta_{1-42}$ peptide aggregation. Using the thioflavin- $T$ (ThT) assay, the ability of resveratrol to reduce the extent of $A \beta_{1-42}$ peptide aggregation was confirmed. The findings of the present study demonstrate that interaction of resveratrol with $A \beta_{1-42}$ peptide resulted in the cleavage of $A \beta_{1-42}$ peptide into smaller fragments, as detected by matrix assisted laser desorption ionisation-time of flight (MALDI-TOF) mass spectrometry. Atomic force microscopy (AFM) analyses revealed $A \beta_{1-42}$ peptide, under control conditions, aggregated into oligomers, protofibrils and fibrils, whereas there was a distinct lack of these structures when $A \beta_{1-42}$ peptide was incubated with resveratrol. Following 10 days' incubation of $A \beta_{1-42}$ peptide with resveratrol particles with a mean z-height of $1.940 \mathrm{~nm}$ (range $0.675-3.275 \mathrm{~nm}$ ) were observed, which are characteristic of shorter peptide species. In cell-based studies, resveratrol significantly reduced the cytotoxicity of $\mathrm{A} \beta_{1-42}$ peptide towards SH-SY5Y human neuroblastoma cells, suggesting a protective effect of the polyphenol. We therefore propose a novel mechanism by which resveratrol disrupts $A \beta_{1-42}$ aggregation by mediating fragmentation of $A \beta_{1-42}$ into smaller peptides, which have no propensity to aggregate further.
\end{abstract}


Graphical abstract

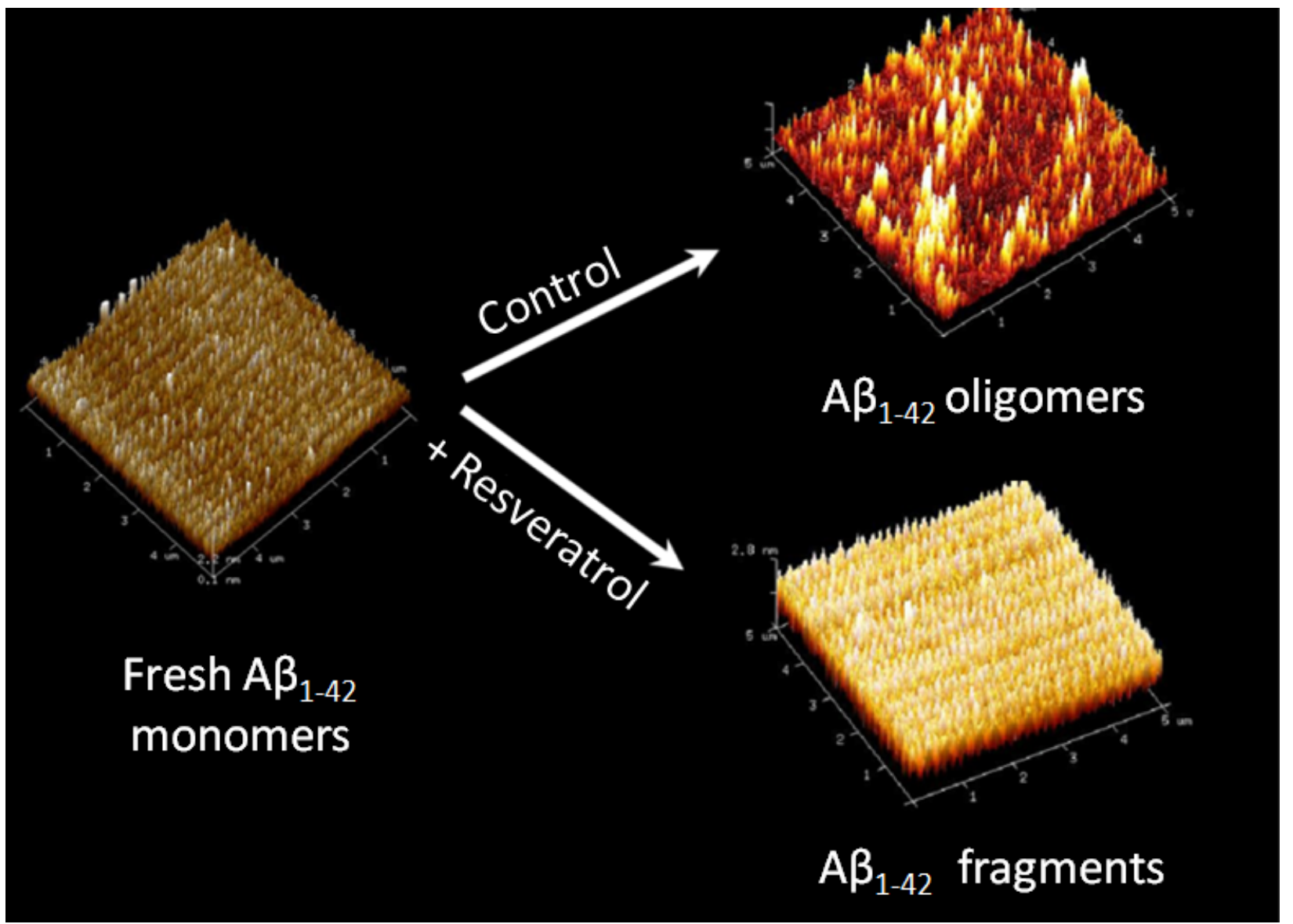

Keywords: Resveratrol; $A \beta_{1-42}$ peptide; cleavage; MALDI-TOF, Alzheimer's disease

\section{Introduction}

Alzheimer's disease (AD), the most common cause of dementia, is a terminal progressive neurodegenerative disease, which destroys brain neurones causing loss of memory and a severe decline in cognitive function (Regitz et al., 2015). To date, there is no effective treatment for $\mathrm{AD}$, and strategies are aimed at managing, rather than curing or preventing, the condition (Bhushan et al., 2018). The aetiology of AD is not completely understood: aspects of the pathology of the disease have been identified and include aggregation of $A \beta_{1-42}$ peptide into fibrils, and subsequent deposition of $A \beta_{1-42}$ peptide-containing plaques, which is 
recognised as the major cause of $\mathrm{AD}$ ( $\mathrm{Li}$ et al., 2011), together with the formation of tau neurofibrillary tangles (Fiala and Veerhuis, 2010).

Resveratrol is a stilbene compound first identified in the roots of white hellebore, Veratrum grandiflorum (Aggarwal et al., 2004). Resveratrol has received much interest due to its benefits to human health (Baur and Sinclair, 2006, Sales and Resurreccion, 2014), which include anti-cancer, anti-inflammatory, anti-aging and cardio-protective properties. Resveratrol has also been reported to possess anti-oxidant properties, chelating properties and scavenging capability towards reactive oxygen species (Belguendouz et al., 1997).

A number of studies have reported resveratrol inhibits aggregation of $A \beta_{1-42}$ monomers in vitro. However, the precise and definitive mechanism(s) by which the polyphenol inhibits aggregation is unknown. Feng et. al., (2009) suggested that inhibition of $A \beta_{1-42}$ monomers into fibrils was due to direct binding of the polyphenol to $A \beta_{1-42}$ (Feng et al., 2009), consistent with atomic force microscopy studies reporting resveratrol was able to bind to the $\mathrm{N}$-terminus of A $\beta_{1-42}$ monomers (Fu et al., 2014). In discrete molecular dynamics simulations, NedumpullyGovindan et. al., (2016) reported resveratrol interacted with the islet amyloid polypeptide amylin via a combination of hydrogen bonding, $\pi-\pi$ stacking and hydrophobic interactions (Nedumpully-Govindan et al., 2016) whilst, in studies with the $\mathrm{A} \beta_{17-36}$ peptide, Wang et. al., (2017) reported resveratrol bound only to the hydrophobic residues near the peptide termini (Wang et al., 2017).

In other studies employing surface plasmon resonance and NMR analyses, Ge et. al., (2012) confirmed direct binding between resveratrol and A $\beta$ monomers and fibrils (Ge et al., 2012) and also reported that resveratrol stained senile plaques in brain slices from Alzheimer's disease patients. 
Studies also documented the ability of resveratrol derivatives to bind amyloid beta, and subsequently disrupt aggregation. Xu et. al., (2017) reported deferiprone-resveratrol hybrids inhibited aggregation of $\mathrm{A} \beta_{1-42}(\mathrm{Xu}$ et al., 2017), Puksacook et. al.,(2017) reported prenylated resveratrol derivatives inhibited aggregation of $\mathrm{A} \beta_{1-42}$ (Puksasook et al., 2017), and Lan et. al., (2018) reported a resveratrol-indazole hybrid inhibited aggregation of $\mathrm{A} \beta_{1-42}$ (Lan et al., 2018).

Whilst multiple studies report the ability of resveratrol, and resveratrol derivatives, to bind to amyloid beta monomers and fibrils, and to inhibit amyloid beta aggregation, the precise mechanism by which resveratrol actually disrupts aggegation is not well understood. In this study we investigated the ability of resveratol to inhibit aggregation of the peptide by disruption of $A \beta_{1-42}$ structure and report a novel mechanism of resveratol-mediated fragmentation of $A \beta_{1-}$ 42 peptide.

\section{Materials and Methods}

\subsection{Materials}

Ultra pure $A \beta_{1-40}$ peptide recombinant type was purchased from rPeptide, UK. $A \beta_{1-42}$ was purchased from the American Peptide Company, CA, USA. 2,2'-Azobis (2-methyl propionamidine) dihydrochloride (AAPH), Thioflavin T (ThT), resveratrol, trifluoroacetic acid (TFA), Dulbecco's Phosphate Buffered Saline (PBS), polycarbonate filters (Whatman ${ }^{\circledR}$ Nuclepore $^{\mathrm{TM}}$ Track-Etched membranes, $25 \mathrm{~mm}$ diameter with pore sizes of $0.05 \mu \mathrm{m}, 0.1 \mu \mathrm{m}$, $0.2 \mu \mathrm{m})$ and dimethyl sulfoxide (DMSO) were purchased from Sigma-Aldrich, UK. Acetonitrile (ACN) (HPLC grade) and Milli-Q water (HPLC grade) were purchased from Fischer Scientific, UK. Hexafluoroisopropanol (HFIP) was from SynQuest Laboratories, Inc., UK. $\alpha$-Cyano-4-hydroxycinnamic acid (CHCA) was purchased from Fluka, UK. Syringe filters (diameter $13 \mathrm{~mm}$ PTFE and pore size $0.22 \mu \mathrm{m}$ NSTR) and centrifuge tube filters (Ultracel-30 with $30 \mathrm{kDa}$ pore size) were purchased from Fisher. The SH-SY5Y cell line was obtained from 
ATCC and cell culture grade DMSO, PBS without $\mathrm{Ca}^{2+} / \mathrm{Mg}^{2+}, 0.25 \%$ trypsin, $0.53 \mathrm{mM}$ EDTA in HBSS without $\mathrm{Ca}^{2+} / \mathrm{Mg}^{2+}$ and thiazolyl blue tetrazolium bromide (MTT) (suitable for cell culture $\geq 97.5 \%$ TLC) were obtained from Sigma-Aldrich. Eagle's Minimum Essential Medium (1X), Ham's F-12 medium, foetal bovine serum (FBS), $1 \%$ L-glutamine, $1 \%$ penicillin/streptomycin, $1 \%$ non-essential amino acids and phenol red free OPTI-MEM medium (1X) were obtained from Invitrogen (UK). 96-well polystyrene plates for cell culture were from Thermo Scientific (UK). All other reagents were of analytical grade and commercially available.

\subsection{Preparation of monomeric $A \beta_{1-40}$ and $A \beta_{1-42}$ peptides}

Monomeric $A \beta_{1-40}$ and $A \beta_{1-42}$ peptides were produced as described previously (Attanasio et al., 2013, Orre et al., 2013). A $\beta$ peptide was dissolved in TFA and filtered using a $13 \mathrm{~mm}$ PTFE syringe filter $(0.22 \mu \mathrm{m}$ pore size $)$. Subsequently, TFA was evaporated using dry nitrogen gas. A $\beta$ peptide was then treated with $2 \mathrm{ml}$ of $1 \%(\mathrm{v} / \mathrm{v})$ HFIP, the sample mixed at room temperature for 15 min and then evaporated to dryness. $A \beta_{1-40}$ and $A \beta_{1-42}$ peptide were freeze-dried under vacuum for $2 \mathrm{~h}$ at $20 \mathrm{mbar}$ and $-50{ }^{\circ} \mathrm{C}\left(\right.$ Christ $^{\circledR}$, Osterode, Germany) and stored under desiccated conditions at $-20^{\circ} \mathrm{C}$ until use.

\subsection{Aggregation of $A \beta_{1-42}$ peptide}

Aggregation of $\mathrm{A} \beta_{1-42}$ peptide was monitored using the ThT assay as described previously (Reyes Barcelo et al., 2009, Bohrmann et al., 2012). Lyophilised A $\beta_{1-42}$ peptide was dissolved to a concentration of $20 \mathrm{mM}$ in DMSO and then diluted to $200 \mu \mathrm{M}$ in Milli-Q water. ThT, $20 \mu \mathrm{M}$, was prepared in $50 \mathrm{mM}$ glycine in Milli-Q water, $\mathrm{pH}$ 8.5. Resveratrol, $20 \mathrm{mM}$, was prepared in DMSO:PBS (4.5:5.5) for studies with $A \beta_{1-42}$ peptide:resveratrol at 1:100. In studies with $A \beta_{1-42}$ peptide:resveratrol at 1:0.01, 1:0.1, 1:1 and 1:10, the $20 \mathrm{mM}$ stock solution was diluted in DMSO:PBS (4.5:5.5) such that $5 \mu$ provided the required resveratrol 
concentration. $A \beta_{1-42}$ peptide solution, $5 \mu$, was added to $5 \mu$ of resveratrol solution and then immediately transferred into individual wells of black 96-well plates containing $90 \mu \mathrm{ThT}$ solution. In control studies, resveratrol was incubated with ThT in the absence $\mathrm{A} \beta_{1-42}$ peptide, and with $A \beta_{1-42}$ peptide in the absence of ThT. Plates were sealed using adhesive tape and incubated at $37{ }^{\circ} \mathrm{C}$ for 10 days. Aggregation was monitored by measuring ThT fluorescence using a Tecan Safire microplate reader (MTX lab systems, USA), with a $3 \mathrm{~s}$ shake prior to each fluorescence reading, at excitation and emission wavelengths of $440 \mathrm{~nm}$ and $495 \mathrm{~nm}$ respectively.

\subsection{High performance liquid chromatography}

High performance liquid chromatography (HPLC) was carried out to investigate the effect of resveratrol on $A \beta_{1-42}$ peptide aggregation over time. $A \beta_{1-42}$ peptide $(100 \mu \mathrm{M})$ was incubated at $37^{\circ} \mathrm{C}$ with resveratrol at an $\mathrm{A} \beta_{1-42}$ peptide:resveratrol molar ratio of 1:100, and samples were removed at $0,16,20$ and $22 \mathrm{~h}$ for detection of $\mathrm{A} \beta_{1-42}$ peptide. Separation was performed as described by the American Peptide Company using a PLRP-S column and a HPLC LC 200 system (PerkinElmer, UK) fitted with a UV-detector. Mobile phase A was 0.05 M pH 6.8 Tris in Milli-Q water, while mobile phase B was 0.05 M Tris pH 6.8 in $80 \%$ (v/v) ACN. The HPLC column was equilibrated in $80 \%$ mobile phase A and $20 \%$ mobile phase B. Samples were loaded and gradient elution was performed with a change in mobile phase from $20 \%$ mobile phase $\mathrm{B}$ to $100 \%$ mobile phase $\mathrm{B}$ over 20 min. A $\beta 1_{-42}$ peptide was detected at 215 nm.

\subsection{Mass laser desorption ionization time-of-flight (MALDI-TOF) spectrometry}

The effect of resveratrol on the aggregation of $A \beta_{1-42}$ peptide over time was analysed by matrix assisted laser desorption ionization time-of-flight (MALDI-TOF) spectrometry, as 
peptide aggregation decreases the amount of detectable free monomer (McGowan et al., 2005, Zovo et al., 2010).

$\mathrm{A} \beta_{1-42}$ peptide $(100 \mu \mathrm{M})$ and resveratrol $(10 \mathrm{mM})$ were incubated in $\mathrm{PBS}, \mathrm{pH} 7.4$, at 37 ${ }^{\circ} \mathrm{C}$ for 10 days (Stine et al., 1996). Matrix was prepared as a saturated solution of $\alpha$-cyano-4hydroxycinnamic acid (CHCA). A saturated solution of CHCA was prepared by dissolving 10 $\mathrm{mg}$ in $1 \mathrm{ml}$ of $70 \% \mathrm{ACN}: 30 \%$ of $0.1 \%$ TFA in Milli-Q water as described by Zoho and colleagues (Zovo et al., 2010).

$A \beta_{1-42}$ peptide samples were mixed with matrix at a ratio of $1: 10$, spotted onto metal plates, air-dried for 20 min and immediately analysed using a MALDI-TOF spectrometer (Shimadzu Biotech Axima Confidence, Japan) equipped with a $337 \mathrm{~nm}$ nitrogen laser operating at $3.0 \mathrm{~Hz}$ in linear mode geometry. The laser intensity was in the range of $5000-6000 \mathrm{~W} . \mathrm{cm}^{-}$ 2 and the consecutive laser shots were between 1000 and 4000. The delay in the pulsed ion extraction time was $700 \mathrm{~ns}$ with ions accelerated at $20 \mathrm{kV}$. The mass/charge $(\mathrm{m} / \mathrm{z})$ data were collected as three repetitions of 100 consecutive laser irradiation clusters, producing three spectra per sample per well. The systematic artefact bias was avoided by randomization of samples for data acquisition.

\subsection{Atomic force microscopy}

Atomic force microscopy (AFM) was used to study $A \beta_{1-42}$ peptide aggregation as described previously (Kowalewski and Holtzman, 1999, Nichols et al., 2005, Cohen et al., 2006). $\mathrm{A} \beta_{1-42}$ peptide $(100 \mu \mathrm{M})$ and resveratrol $(10 \mathrm{mM})$ were incubated in PBS, $\mathrm{pH} 7.4$, at 37 ${ }^{\circ} \mathrm{C}$ for 10 days (Stine et al., 1996). Freshly cleaved mica was mounted on a metal disc and 20 $\mu \mathrm{l}$ samples were deposited on the mica for 20 min (Ostapchenko et al., 2012). Samples were washed five times with filter sterilised Milli-Q water, air dried at room temperature and analysed using a Picoforce Nanoscope V Multimode atomic force microscope (Bruker) using 
tapping mode with scan rates between 0.5 and $1.5 \mathrm{~Hz}$ and a resonant frequency range of 270 $460 \mathrm{kHz}$. Image capturing was conducted after specifying representative areas. The resolution of the images was $512 \times 512$ points and the height and amplitude error mode images $(5 \mu \mathrm{m} \times$ $5 \mu \mathrm{m})$ were used after flattening using Nanoscope software v7.2.

\subsection{SH-SY5Y cell culture}

SH-SY5Y neuroblastoma cells were maintained as described by (Ross et al., 1983). SH-SY5Y cells were cultured in growth medium composed of a 1:1 mixture of Eagle's Minimum Essential Medium and Ham's F12 Medium, containing $10 \%$ foetal bovine serum (FBS) at $37^{\circ} \mathrm{C}$ and in an atmosphere of $5 \%$ carbon dioxide $\left(\mathrm{CO}_{2}\right)$.

\subsection{Measurement of cell viability using the MTT assay}

The effects of $A \beta_{1-42}$ peptide and resveratrol on the viability of SH-SY5Y cells were determined as previously described (Abe and Matsuki, 2000). Cells were plated at a density of $1.5 \times 10^{4}$ cells/well in 96-well plates and left to adhere overnight. Cells were incubated with either $10 \mu \mathrm{M} A \beta_{1-42}$ peptide, $1 \mu \mathrm{M}$ resveratrol or $10 \mu \mathrm{M} A \beta_{1-42}$ peptide and $1 \mu \mathrm{M}$ resveratrol

combined in $100 \mu \mathrm{l}$ growth medium for $48 \mathrm{~h}$ at $37{ }^{\circ} \mathrm{C}, 5 \% \mathrm{CO}_{2}$. Twenty five microliters of MTT (5 mg. $\left.\mathrm{ml}^{-1}\right)$ were then added to each well and the cells incubated for a further $4.5 \mathrm{~h}$ at 37 ${ }^{\circ} \mathrm{C}$ in $5 \% \mathrm{CO}_{2}$. Growth medium was then removed, monolayers washed three times with PBS and $100 \mu \mathrm{l}$ of $50 \% \mathrm{~N}, \mathrm{~N}$-dimethyl-formamide and $20 \%$ SDS added to each well. Plates were incubated overnight at $37{ }^{\circ} \mathrm{C}$ and the absorbance measured at a test wavelength of $570 \mathrm{~nm}$ and a reference wavelength of $655 \mathrm{~nm}$ using a Polar Star Omega plate reader.

\subsection{Statistical analysis}

Data are expressed as mean \pm standard deviation of at least three independent experiments, each containing at five replicates. Multiple comparisons were made using 
repeated measures ANOVA and Student's t-test was carried out using IBM SPSS software v20 and Design-Expert ${ }^{\circledR}$ software v9. Differences were considered to be statistically significant when $\mathrm{p}<0.05$.

\section{Results and discussion}

\subsection{Resveratrol reduces aggregation of $A \beta_{1-42}$ peptide}

Studies were carried out to investigate the ability of resveratrol to inhibit aggregation of monomeric $A \beta_{1-42}$ peptide at $A \beta_{1-42}$ peptide:resveratrol molar ratios of 1:0.01, 1:0.1, 1:1, 1:10 and 1:100. These studies revealed significant reductions in ThT fluorescence following resveratrol treatment, with reductions reflecting a concentration-dependent anti-aggregation effect of the polyphenol (Fig 1). It is notable that, at an $A \beta_{1-42}$ peptide:resveratrol molar ratio of 1:100, fluorescence emission was almost completely abolished with resveratrol treatment, suggesting that the new non-aggregated structures formed were no longer able to bind ThT, unlike the starting monomeric $A \beta_{1-42}$ peptide. It should be noted however, that there is a slight possibility of interaction between resveratrol and thioflavin, which is a potential limitation in this study. 


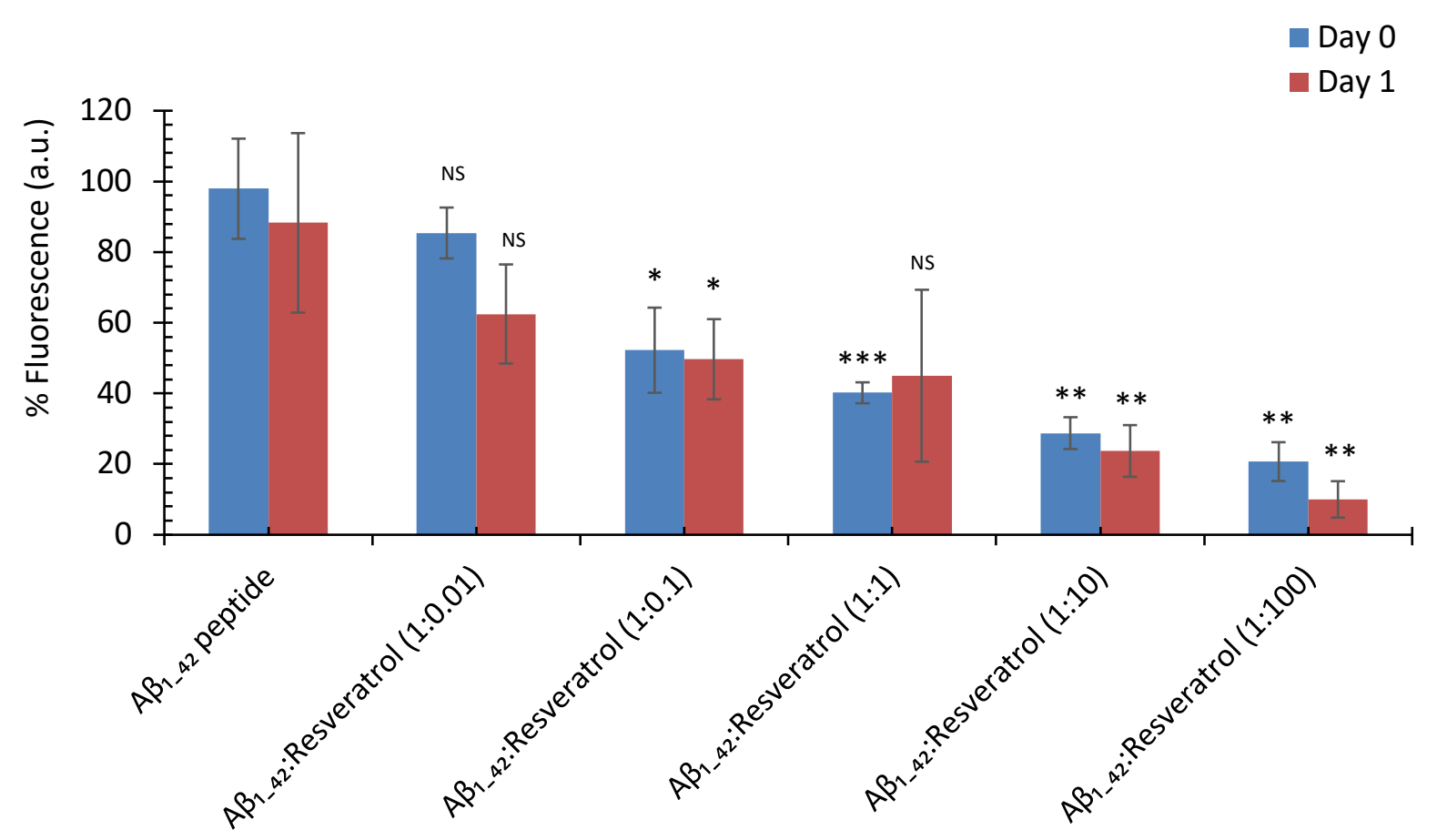

Figure 1. Effect of resveratrol on the aggregation of $A \beta_{1-42}$ peptide. $A \beta_{1-42}$ peptide was prepared by solubilising in TFA, evaporating to dryness using dry nitrogen gas and solubilising in $1 \%(\mathrm{v} / \mathrm{v})$ HFIP. The solvent was then evaporated and the $\mathrm{A} \beta_{1-42}$ peptide stored at $-20^{\circ} \mathrm{C}$. The thioflavin $\mathrm{T}$ assay was carried out in black 96-well plates and fluorescence measured using excitation and emission wavelengths of $440 \mathrm{~nm}$ and $495 \mathrm{~nm}$ respectively. Data are represented as mean \pm standard deviation of three independent experiments each containing at five replicates and were analysed by repeated measures ANOVA to compare fluorescence at each individual time point with fluorescence at day 0. * $\mathrm{p}<0.05, * * \mathrm{p}<0.01$ and $* * * \mathrm{p}<0.001$ and NS not significant.

In control studies, where resveratrol was incubated with ThT over 10 days in the absence of $A \beta_{1-42}$ peptide, fluorescence levels were low (due to the absence of aggregated $A \beta_{1-}$ 42 peptide) and there was no significant change in the level of fluorescence over time (data not shown). Furthermore, when monomeric $A \beta_{1-42}$ peptide was incubated with resveratrol over 10 days, fluorescence levels were low (due to the absence of ThT) and there was no significant change in the level of fluorescence over time (data not shown). 
The results of the current study are consistent with those of Guo et. al., (2010) who demonstrated that resveratrol inhibited $A \beta_{1-42}$ aggregation (Guo et al., 2010), with an effective dose of $40.8 \mathrm{nM}$ reducing aggregation by $50 \%$ and those of Richard et. al., (2011) who reported resveratrol inhibited both $A \beta_{1-42}$ and $A \beta_{1-40}$ fibril formation (Richard et al., 2011). The findings are also consistent with the study of Lu et. al., (2012), which reported that resveratrol inhibited A $\beta_{1-42}$ aggregation by $69.73 \%$ (Lu et al., 2012) and the study of Kantham et. al., (2017) which demonstrated resveratrol significantly inhibited formation of $A \beta_{1-42}$ oligomers and fibrils and

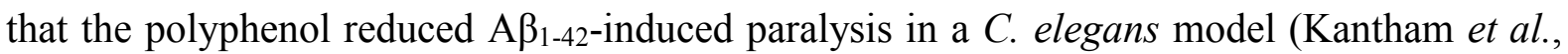
2017). Similar findings have also been observed in vivo, where it was reported that resveratrol markedly reduced amyloid plaque formation in 45 day old Tg19959 mice (Walle, 2011).

\subsection{Resveratrol causes fragmentation of $A \beta_{1-42}$ peptide}

The temporal effect of resveratrol treatment on monomeric $A \beta_{1-42}$ peptide was analysed using high-performance liquid chromatography (HPLC). In control studies without resveratrol, the retention time of intact monomeric $\mathrm{A} \beta_{1-42}$ peptide was 8.47 min and no peaks corresponding to fragments of $A \beta_{1-42}$ peptide were observed (Fig. 2). Over time, there was a decrease in the peak height corresponding to $A \beta_{1-42}$ peptide monomer (Fig. 2 and Supplementary Fig 1), reflecting a decrease in the amount of monomeric $A \beta_{1-42}$ peptide. This is explained by the fact that the peptide may undergo auto-hydrolysis or aggregation (Hosia et al., 2005, Grasso et al., 2009). Auto-hydrolysis can produce fragments which are smaller and more soluble, hence eluting with lower retention times, as apparent in the HPLC profile in Fig 2. A $\beta_{1-42}$ peptide aggregates were not detected by HPLC, as the higher order aggregates are not amenable to 
separation by HPLC due to low solubility, consistent with the finding previously reported (Zhang et al., 2013).

When monomeric $A \beta_{1-42}$ peptide was incubated with resveratrol, the retention time of $\mathrm{A} \beta_{1-42}$ peptide at the start of the incubation was 8.47 min (Fig. 2), consistent with the control condition. In this condition there was also a time-dependent decrease in the peak height corresponding to $A \beta_{1-42}$ peptide monomer, but this decrease was accompanied by a timedependent left shift in the retention time (Fig. 2) suggesting that additional degradation is occurring, mediated by resveratrol.

It is noticeable that the rate of $A \beta_{1-42}$ monomer disappearance in the presence of resveratrol is faster than in the control, lacking resveratrol. In control studies, intact monomeric $\mathrm{A} \beta_{1-42}$ peptide was still detectable at $22 \mathrm{~h}$ (Fig. 2), however when $A \beta_{1-42}$ peptide was incubated with resveratrol, no intact peptide was detected at $22 \mathrm{~h}$ (Fig. 2). To exclude the possibility that the major peak with a retention time of $8.47 \mathrm{~min}$ was due to resveratrol, analyses of the absorption characteristics of both $A \beta_{1-42}$ peptide and resveratrol were carried out. Resveratrol possessed significant absorbance between $250 \mathrm{~nm}$ and $400 \mathrm{~nm}$, but minimal absorbance at 215 $\mathrm{nm}$, indicating that resveratrol was unlikely to interfere with the HPLC analysis of A $\beta_{1-42}$ peptide (data not shown). 
(A)

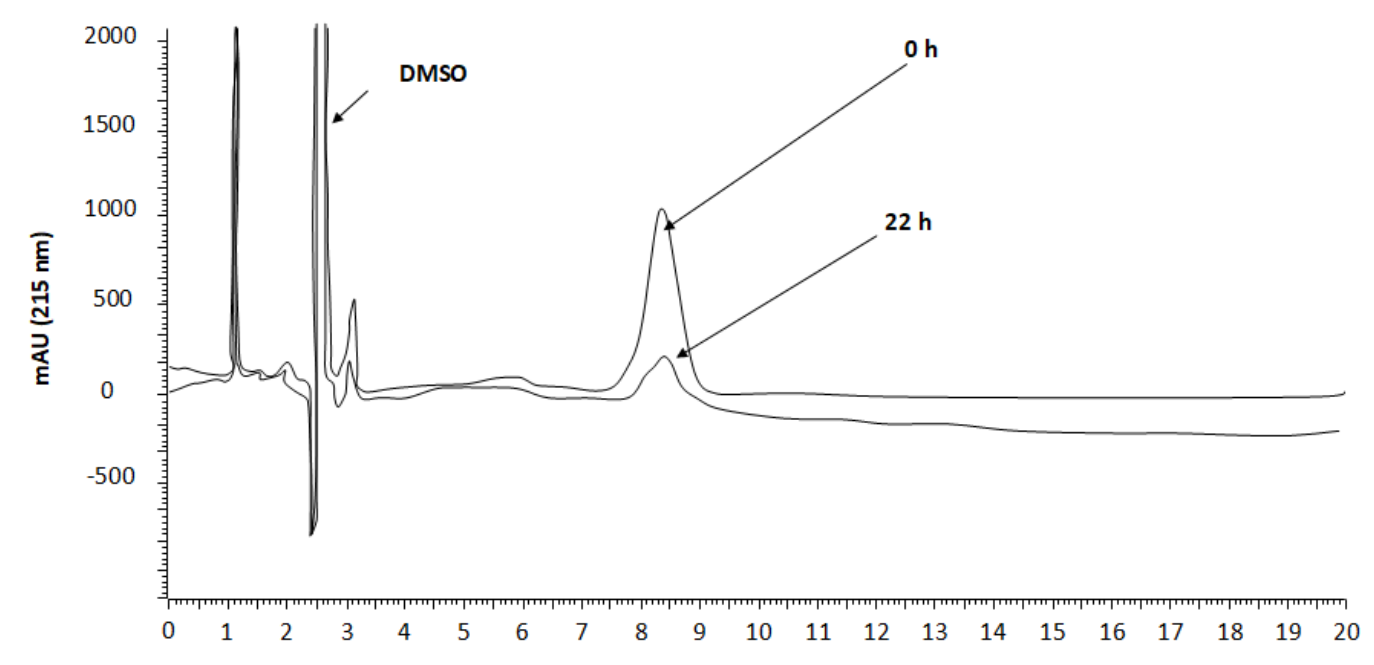

(B)

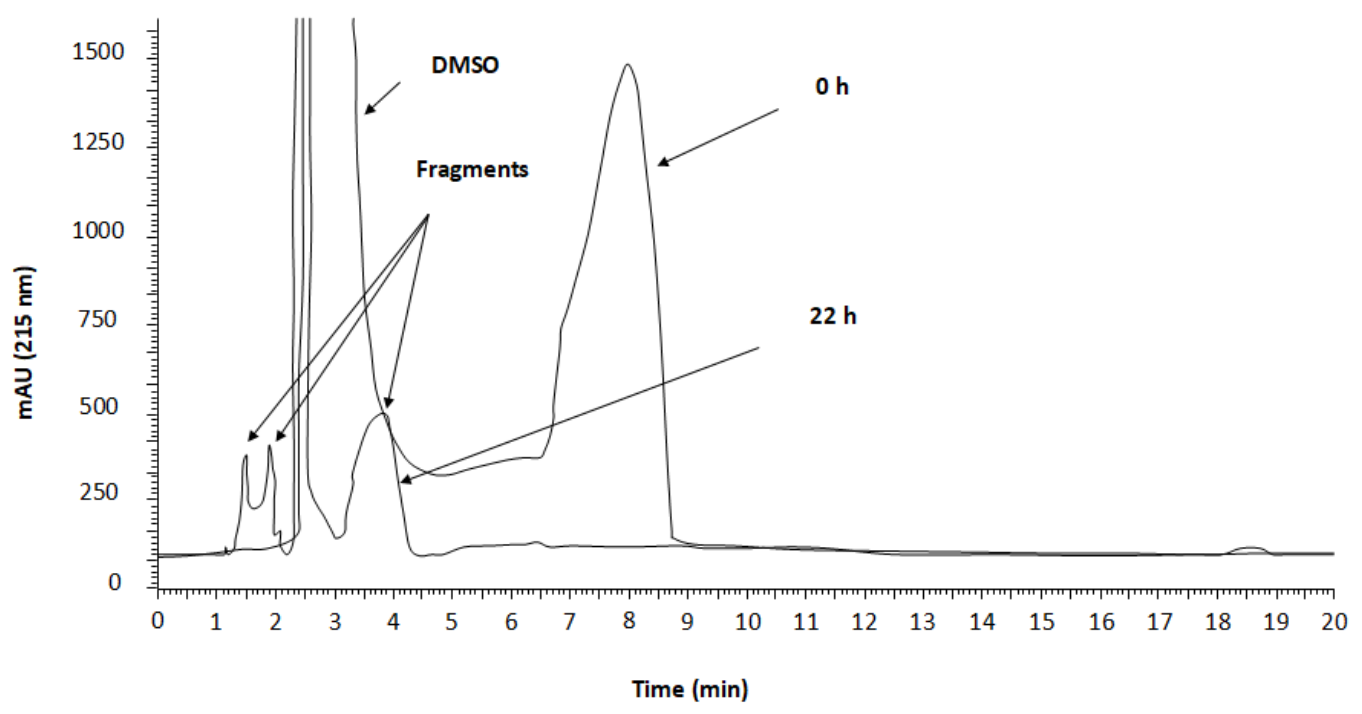

Figure 2. Superimposed HPLC analyses of (A) $A \beta_{1-42}$ peptide, $100 \mu \mathrm{M}$, and (B) $\mathrm{A} \beta_{1-42}$ peptide, $100 \mu \mathrm{M}$, incubated with resveratrol at a 1:100 molar ratio, at $0 \mathrm{~h}$ and $22 \mathrm{~h}$.

The findings of the present study are consistent with those of Naslund et. al., (1996), who confirmed loss of residues from the $\mathrm{N}$-terminal of $\mathrm{A} \beta_{1-42}$ peptide resulting in a more lipophilic peptide, with an increased retention time, while loss of residues from the C-terminal of $\mathrm{A} \beta_{1-42}$ peptide gave peaks with a decreased retention time (Naslund et al., 1996). In our 
studies, when $A \beta_{1-42}$ peptide was incubated with resveratrol for $20 \mathrm{~h}$, peaks were observed at retention times between $1-4$ min, indicating more hydrophilic (i.e. polar) peptide fragments.

The A $\beta$ peptide exists in several forms, and many studies have been carried out using the $A \beta_{1-40}$ peptide rather than the $A \beta_{1-42}$ form. Therefore, we initially investigated the ability of resveratrol to cleave monomeric $A \beta_{1-40}$ peptide. The MALDI-TOF analysis of $A \beta_{1-40}$ in control conditions (without resveratrol) at $24 \mathrm{~h}$ showed a peak corresponding to a $\mathrm{m} / \mathrm{z}$ ratio of 4331 , indicating intact monomeric $A \beta_{1-40}$ peptide (Fig. 3 A). However, following $24 \mathrm{~h}$ incubation with resveratrol, peptide fragments with $\mathrm{m} / \mathrm{z}$ ratio between 1032 - 1826 were observed, with no intact monomeric $A \beta_{1-40}$ peptide detected (Fig. 3 B). The differences between the consecutive peaks from left to right (Fig. 3) are 128, 138, 137, 99, 129 and 163, corresponding to the residual mass of glutamine $(\mathrm{Q})$, histidine $(\mathrm{H})$, histidine $(\mathrm{H})$, valine $(\mathrm{V})$, glutamic acid $(\mathrm{E})$ and tyrosine (Y), respectively, with the peak at $\mathrm{m} / \mathrm{z} 1826$ consistent with the DAEFRHDSGYEVHHQ fragment. The absence of peaks corresponding to the fragments right of the cleavage sites suggests that the peptides have been hydrolysed to small fragments in the matrix region of the MALDI spectrum, below $\mathrm{m} / \mathrm{z} 1000$. The absence of hydrolysis products on the first day of incubation of monomeric $A \beta_{1-40}$ peptide with resveratrol suggests that there is a lag time before the start of hydrolysis, which might be driven by oxidation products of resveratrol. The possible sites of oxidation of resveratrol are the m-hydroquinone moiety, to produce m-semiquinone radicals and the phenol moiety which produces phenoxy radicals (Sako et al., 2004). Resveratrol is proposed to modulate $\mathrm{A} \beta$ aggregation by the same mechanism as the oxidation product of dopamine, dopamine quinone (by forming a covalent adduct with a tyrosine residue of $\mathrm{A} \beta$ ) (Kapurniotu, 2004) or as baicalein (Zhu et al., 2004) by forming a Schiff base with a lysine residue of A $\beta$ (Petkova et al., 2002). 
(A)

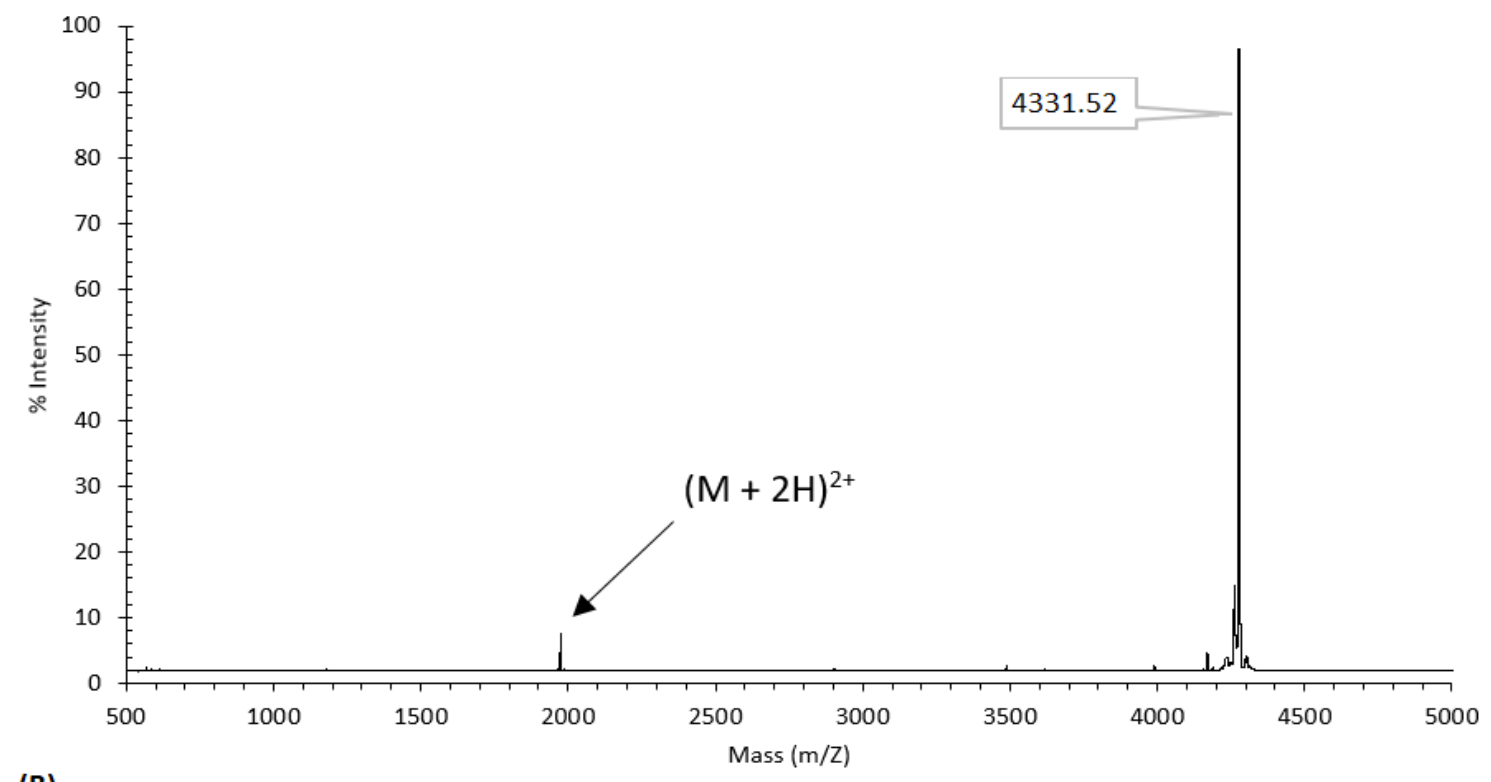

(B)

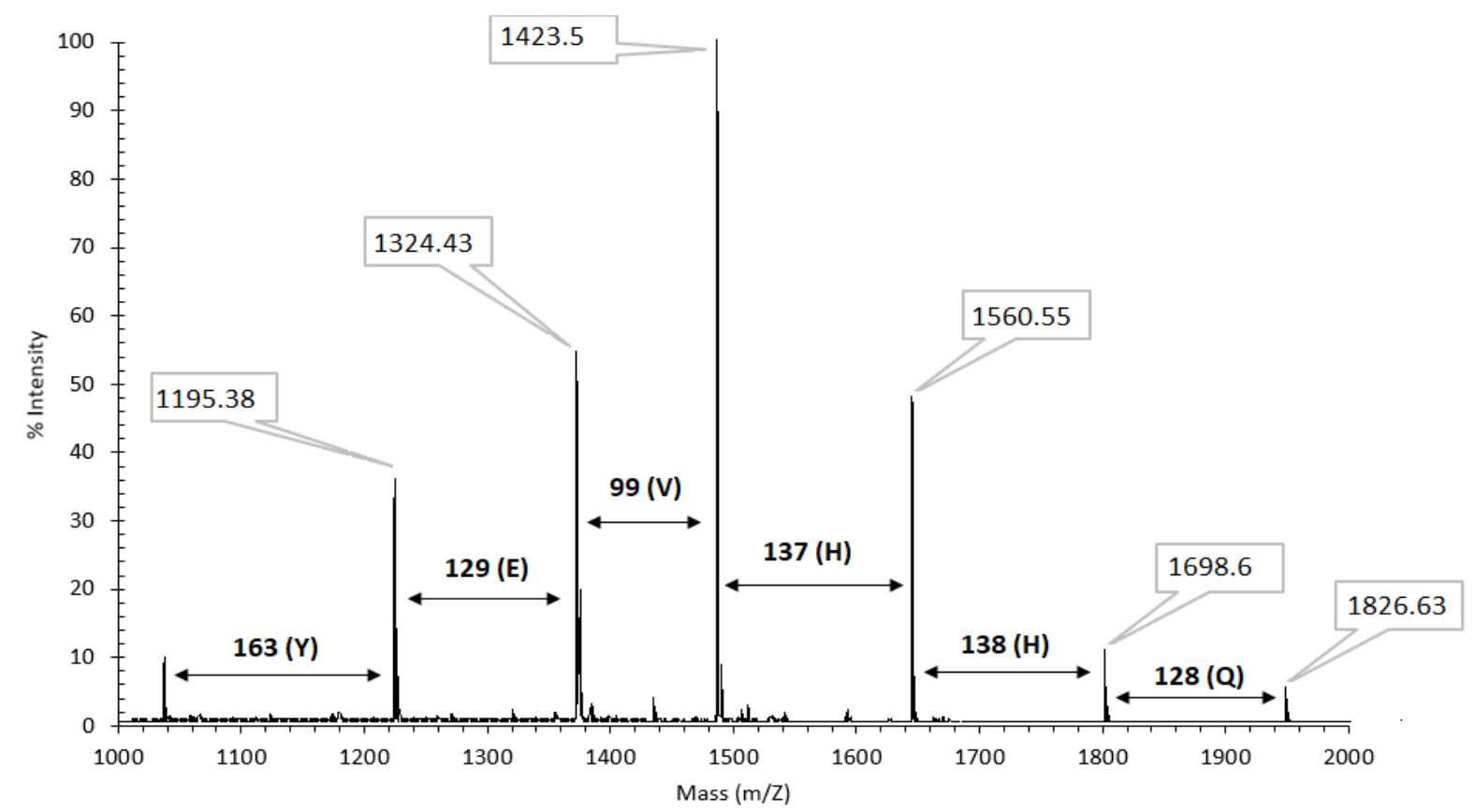

Figure 3. MALDI-TOF spectra of $A \beta_{1-40}$ peptide in the absence and presence of resveratrol. $A \beta_{1-40}$ peptide solution $(100 \mu \mathrm{M})$ was freshly prepared in $0.1 \%$ DMSO in Milli-Q water. (A) A $\beta_{1-40}$ peptide solution was mixed with matrix ( $70 \% \mathrm{ACN}$ : $0.1 \% \mathrm{TFA})$ at an $\mathrm{A} \beta_{1-40}$ peptide:matrix ratio of $1: 10$ and samples spotted onto metal plates, air-dried for $20 \mathrm{~min}$ and immediately analysed using a MALDI-TOF spectrometer (Shimadzu Biotech Axima Confidence, Japan). (B) MALDI-TOF analysis of A $\beta_{1-40}$ peptide after 10 days incubation with $10 \mathrm{mM}$ resveratrol at $37^{\circ} \mathrm{C}$. 
MALDI-TOF analysis of freshly prepared $A \beta_{1-42}$ peptide solution $(100 \mu \mathrm{M})$, revealed a peak at $\mathrm{m} / \mathrm{z} 4517.49$ attributed to the monomeric form of $A \beta_{1-42}$ peptide (Fig. $4 \mathrm{~A}$ ). This is consistent with the literature, reporting detection of $A \beta_{1-42}$ peptide monomers using MALDITOF (Hosia et al., 2005, Grasso, 2011). The intact monomeric $A \beta_{1-42}$ peptide was still detected after $20 \mathrm{~h}$, however, it was not the major peak at this time point (Fig. $4 \mathrm{~B}$ ). Following incubation of monomeric $A \beta_{1-42}$ peptide with resveratrol for $20 \mathrm{~h}$, there was a complete absence of intact $\mathrm{A} \beta_{1-42}$ peptide (no peak observed at $\mathrm{m} / \mathrm{z} 4517.49$ ) but a peak at $\mathrm{m} / \mathrm{z} 2258.2$ at half the original value, which is attributed to the diprotonated molecular ion $(\mathrm{M}+2 \mathrm{H})^{2+}$, presumably arising due to a decrease in the $\mathrm{pH}$ on the addition of resveratrol. New multiple protein fragments were also detected (Fig. 4 C) which were consistent with the formation of smaller fragments peptides. 

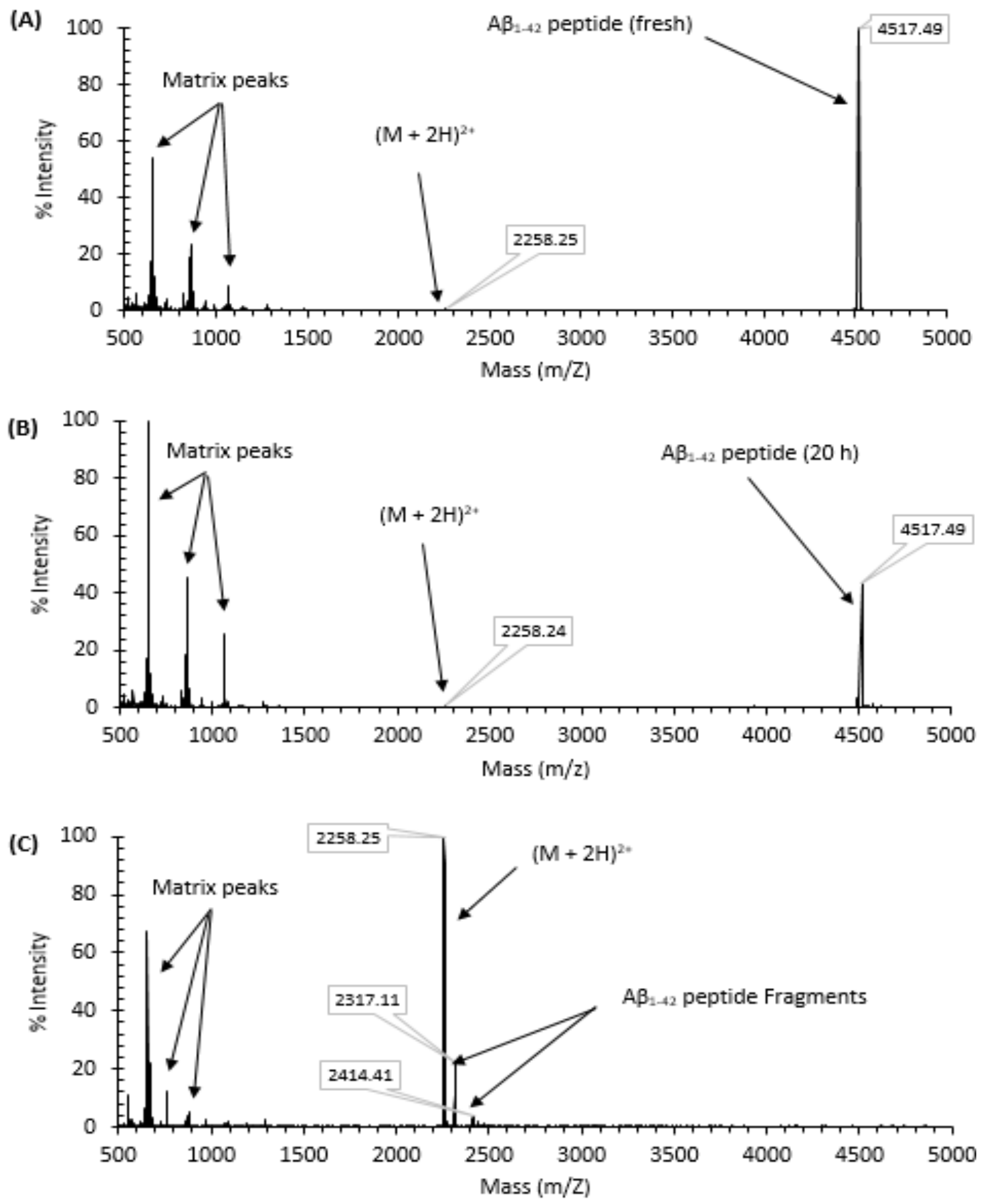

Figure 4. MALDI-TOF spectra of $A \beta_{1-42}$ peptide in the absence and presence of resveratrol. $A \beta_{1-42}$ peptide solution $(100 \mu \mathrm{M})$ was freshly prepared in $0.1 \%$ DMSO in Milli-Q water. (A) A $\beta_{1-42}$ peptide solution was mixed with matrix (70 \% ACN: $0.1 \% \mathrm{TFA})$ at an $\mathrm{A} \beta_{1-42}$ peptide:matrix ratio of 1:10 and samples spotted onto metal plates, air-dried for $20 \mathrm{~min}$ and immediately analysed using a MALDI-TOF spectrometer (Shimadzu Biotech Axima Confidence, Japan). (B) MALDI-TOF analysis of A $\beta_{1-42}$ peptide after $20 \mathrm{~h}$ incubation at $37^{\circ} \mathrm{C}$. (C) MALDI-TOF analysis of $\mathrm{A} \beta_{1-42}$ peptide after $20 \mathrm{~h}$ incubation with $10 \mathrm{mM}$ resveratrol at $37^{\circ} \mathrm{C}$. 
The intensity of the $A \beta_{1-42}$ peptide $(\mathrm{M}+\mathrm{H})^{+}$peak was dramatically decreased after $20 \mathrm{~h}$ of incubation at $37{ }^{\circ} \mathrm{C}$, indicating a decrease in the monomeric form of $\mathrm{A} \beta_{1-42}$ peptide, due to aggregation and the likely formation of larger species (Fig. 4). Bartolini et. al., (2007) reported that fibrils, protofibrils and oligomers are not detectable by MALDI-TOF due to their inability to ionise (Bartolini et al., 2007), in agreement with our findings.

The possible protein sequences for the fragment with $\mathrm{m} / \mathrm{z}$ of 2317.11 and the fragment with $\mathrm{m} / \mathrm{z}$ of 2414.41 derived from $\mathrm{A} \beta_{1-42}$ peptide were identified using ProteinCalculator (v3.4) (http://protcalc.sourceforge.net/cgi-bin/protcalc). The theoretical isotope patterns for the sequences were matched with the experimental isotope patterns from MALDI-TOF (Table 1). The fragment at $\mathrm{m} / \mathrm{z}$ of 2317.10 does not seem to correspond to any specific peptide sequence and it may have been chemically modified by resveratrol. The fragment with $\mathrm{m} / \mathrm{z}$ of 2414.40 revealed one matched sequence corresponding to fragment $A \beta_{5-24}$, Table 1 . This corresponds to cleavage between Phe4 - Arg5 of the $A \beta_{1-42}$ peptide and between Val24 - Gly25. The latter is adjacent to the site in $\mathrm{A} \beta_{1-40}$ where auto-hydrolysis has been reported to cleave between Asp23 - Val24 residues (Hosia et al., 2005, Lyons et al., 2016). Of note, this is the first study to report cleavage at Phe4 - Arg5, which may be the primary site for resveratrol catalysed cleavage of the $A \beta_{1-42}$ peptide, and represents a novel mechanism by which the polyphenol disrupts $A \beta_{1-42}$ peptide aggregation. 
Table 1. Comparison of the experimental (MALDI-TOF) and theoretical isotope patterns (online ChemCalc protein calculator) for the observed peptide fragments.

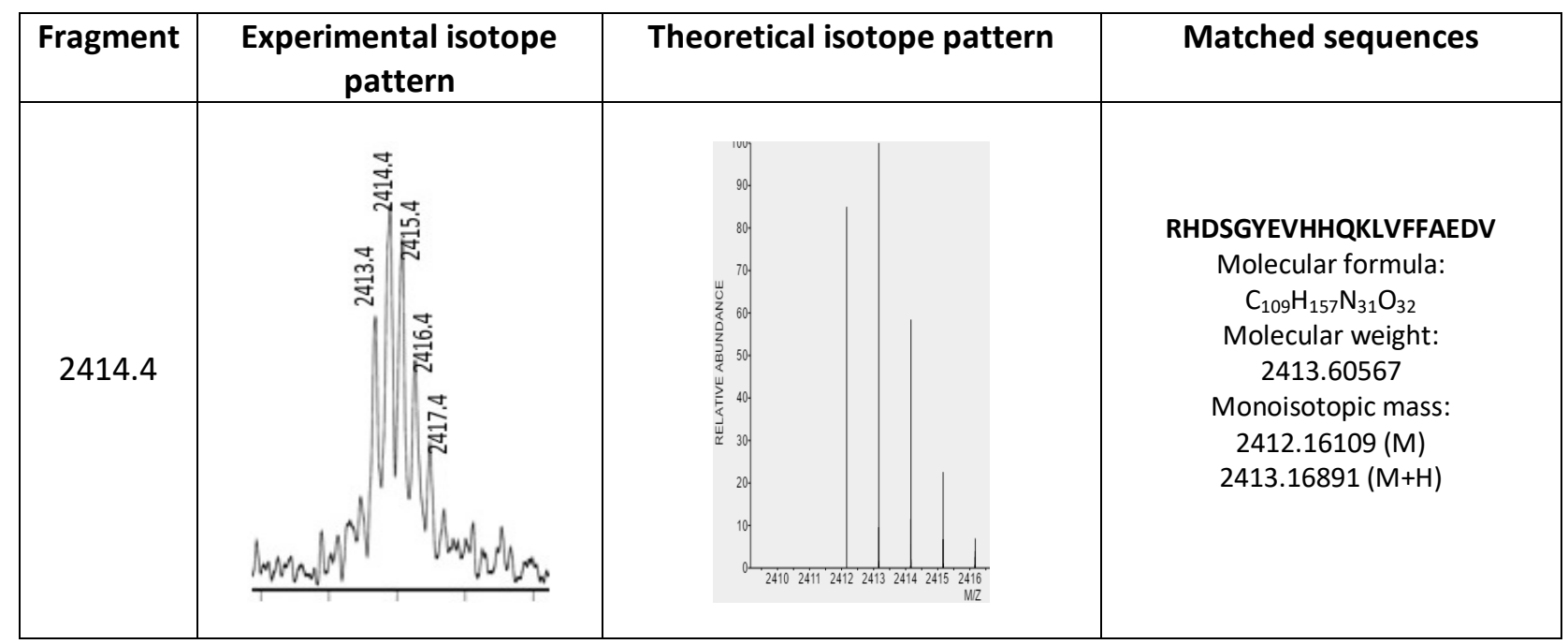

Coskuner and Wise-Scira, 2013 reported that the Arg5 residue in $A \beta_{1-42}$ peptide forms stable salt bridges with various residues (Coskuner and Wise-Scira, 2013). The cleavage of A $\beta$ is known to be dependent on its secondary structure (Naldi et al., 2012, Rudinskiy et al., 2016). An interaction between the guanidinium group and resveratrol may weaken the salt bridge to destabilise the $A \beta_{1-42}$ secondary structure and prevent aggregation. This may be followed by hydrolysis. This is in line with our finding that resveratrol exhibited anti-aggregation activity well before the appearance of peptide fragments. Therefore, interference with this amino acid (by forming bonds between resveratrol and the Arg residue) could be a possible explanation for the mechanism of resveratrol action (Coskuner and Wise-Scira, 2013). Rudinskiy et. al., (2016) highlights the importance of cleavage occurring at Gly25 as the $\mathrm{A} \beta_{1-25}$ peptide has been implicated as a fragment that becomes internalised by neuronal cells and which may be associated with early events of $\mathrm{A} \beta$ aggregation (Rudinskiy et al., 2016). In the case of resveratrol treatment, cleavage at Phe4 - Arg5 will truncate this fragment further to produce $\mathrm{A} \beta_{5-24}$ (RHDSGYEVHHQKLVFFAEDV), which could prevent aggregation of the peptide. 


\subsection{Morphological examination of $A \beta_{1-42}$ peptide using atomic force microscopy}

The effect of resveratrol on aggregation of the $A \beta_{1-42}$ peptide was analysed using atomic force microscopy (AFM). In control AFM studies, without resveratrol, the fresh (Day 0) A $\beta_{1}$ 42 peptide possessed a mean z-height of $1.932 \mathrm{~nm}$ (range $0.846-7.520 \mathrm{~nm}$ ) and samples were free of $A \beta_{1-42}$ fibrils and large aggregates (Fig. $5 \mathrm{~A}$ ), consistent with literature findings (Parbhu et al., 2002). By day 1, the $\mathrm{A} \beta_{1-42}$ peptide oligomers could be observed, the mean z-height of which was $4.238 \mathrm{~nm}$ (range $1.334-23.367 \mathrm{~nm}$ ) (data not shown). At day 3, larger $\mathrm{A} \beta_{1-42}$ peptide oligomers were observed, which possessed a mean z-height of $5.825 \mathrm{~nm}$ (range $1.311-23.521$ $\mathrm{nm}$ ) and very few $\mathrm{A} \beta_{1-42}$ peptide monomers were detected (data not shown), again similar to the literature (Parbhu et al., 2002). Subsequently, on day 4, larger $\mathrm{A} \beta_{1-42}$ peptide oligomers, with a mean z-height of $8.161 \mathrm{~nm}$ (range $4.278-16.252 \mathrm{~nm}$ ) and protofibrils up to $1 \mu \mathrm{m}$ in length were detected (data not shown). Analysis on day 7 revealed the presence of fibrils with mean z-height of $12.145 \mathrm{~nm}$ (range $4.250-43.847 \mathrm{~nm}$ ), and lengths between $1-4 \mu \mathrm{m}$ (data not shown). Analysis on day 10 revealed the presence of larger fibrils with mean z-height of $18.706 \mathrm{~nm}$ (range 2.644 - $35.924 \mathrm{~nm}$ ), and lengths between $1.24-4.5 \mu \mathrm{m}$ observed at day 10 (Fig. 5 B). Analysis on day 10 of $A \beta_{1-42}$ in the presence of resveratrol revealed only cleaved peptides (Fig. 5 C).

Using AFM, Ge et. al., (2012), confirmed that co-incubation of resveratrol with A $\beta_{1-42}$ peptide monomer significantly reduced the aggregation of $A \beta_{1-42}$ peptide, which is consistent with our findings (Ge et al., 2012). The results are also consistent with the findings of Fu et. al., (2014) who assessed the influence of resveratrol on the aggregation of $\mathrm{A} \beta_{1-42}$ peptide using AFM, and proposed that resveratrol binds to the $\mathrm{N}$-terminus of the $\mathrm{A} \beta_{1-42}$ peptide monomers and caps the height of the oligomers (Fu et al., 2014). However, whilst the findings of the present study, and others', reveal resveratrol disrupts $A \beta_{1-42}$ peptide aggregation, Phan et. al., (2019) report resveratrol accelerated the formation of amyloid beta fibrils, before decreasing 
fibrillation (Phan et al., 2019). It is possible this difference may be due to differences in the way $A \beta_{1-42}$ peptides were prepared, with peptides prepared in ammonia solution having a greater propensity to form fibrils than peptides prepared in HFIP. Furthermore, there are slight differences in the experimental conditions, i.e. solvents, under which $A \beta_{1-42}$ peptide aggregation was studied.

(A)

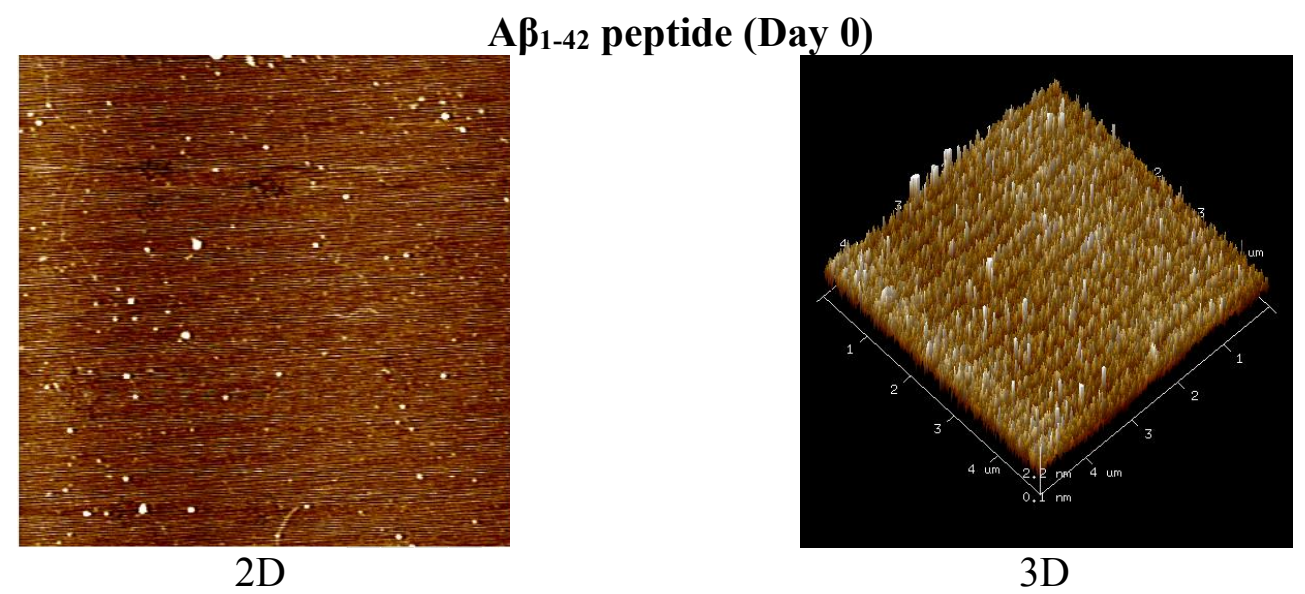

(B)

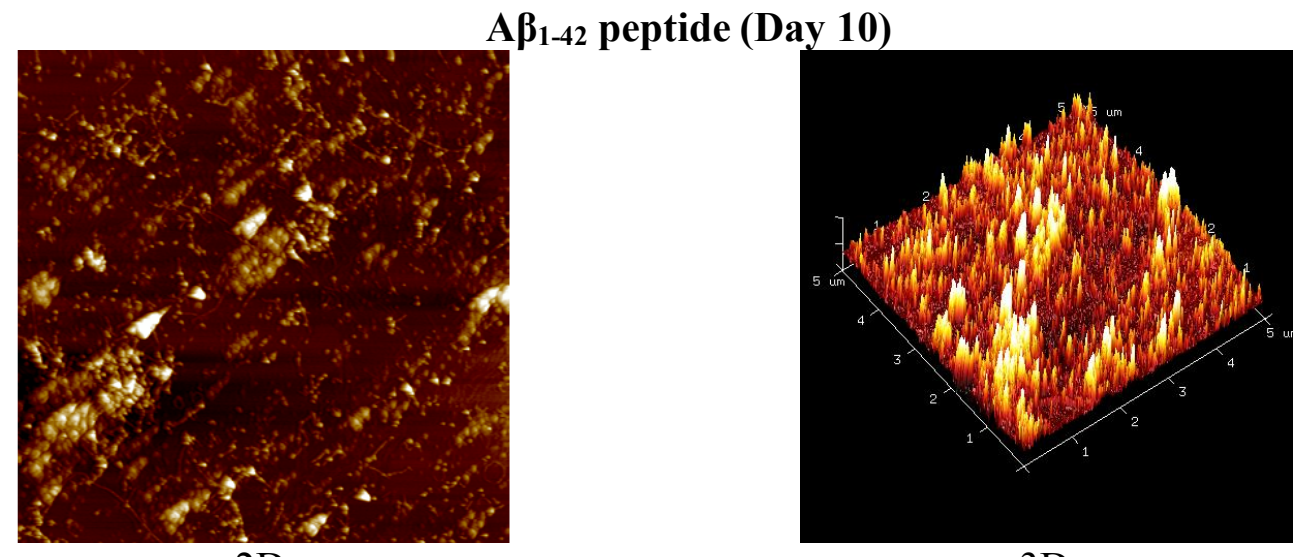

$2 \mathrm{D}$

$3 \mathrm{D}$

(C)

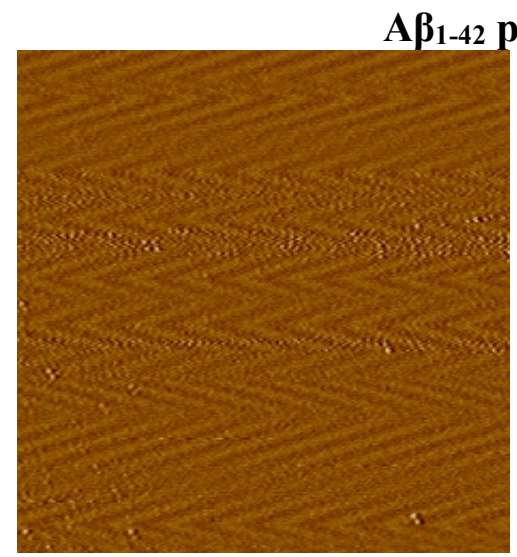

2D

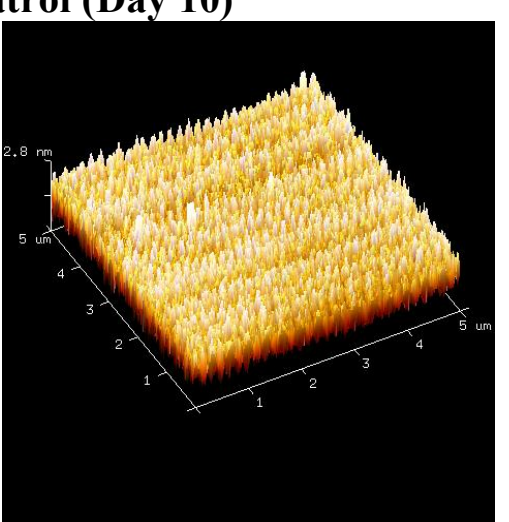

$3 \mathrm{D}$ 
Figure 5. Visualisation of the effect of resveratrol on $A \beta_{1-42}$ peptide aggregation by atomic force microscopic analysis. $A \beta_{1-42}$ peptide $(0.2 \mathrm{mM})$ was incubated with resveratrol $(20 \mathrm{mM})$ at an $A \beta_{1-42}$ peptide:resveratrol molar ratio of $1: 100$ at $37^{\circ} \mathrm{C}$ for 10 days. Samples, $20 \mu 1$, of $\mathrm{A} \beta_{1-42}$ peptide (A, B) or $A \beta_{1-42}$ peptide incubated with resveratrol $(C)$ were then deposited on freshly cleaved mica for 20 min, washed five times with filter sterilised Milli-Q water and air dried at room temperature. Atomic force microscopic analysis was carried out using a Picoforce Nanoscope $\mathrm{V}$ Multimode atomic force microscope at day $0(\mathrm{~A})$ and day $10(\mathrm{~B}, \mathrm{C})$ using tapping mode with scan rates between 0.5 and $1.5 \mathrm{~Hz}$ and a resonant frequency range of $270-460 \mathrm{kHz}$. Scanned areas shown are $5 \times 5 \mu \mathrm{m}$.

\subsection{Resveratrol reduces $A \beta_{1-42}$ peptide toxicity towards SH-SY5Y cells}

The SH-SY5Y human neuroblastoma cell line was chosen to assess the effect of $A \beta_{1-42}$ peptide on cell viability since SH-SY5Y cells have been reported to be sensitive to $A \beta_{1-42}$ peptide (El-Agnaf et al., 1998). Exposure of SH-SY5Y cells to $\mathrm{A} \beta_{1-42}$ peptide resulted in a significant $(\mathrm{P}<0.01)$ reduction in cell viability, from $100 \%$ to $78 \%$, whilst exposure to resveratrol did not affect viability (Fig. 6). Interestingly, when SH-SY5Y cells were coincubated with $A \beta_{1-42}$ peptide and resveratrol (1:10 molar ratio), no $A \beta_{1-42}$ peptide-mediated toxicity was observed (Fig. 6). This finding is consistent with the finding that resveratrol cleaves $A \beta_{1-42}$ peptide into smaller fragments, thereby reducing toxicity towards cells. There is evidence that $A \beta_{1-42}$ peptide-mediated neurotoxicity is induced by $A \beta$ aggregation (Barrow et al., 1992), therefore disruption of the aggregation process is likely to reduce $\mathrm{A} \beta_{1-42}$ peptidemediated neurotoxicity, as observed in the current study. 


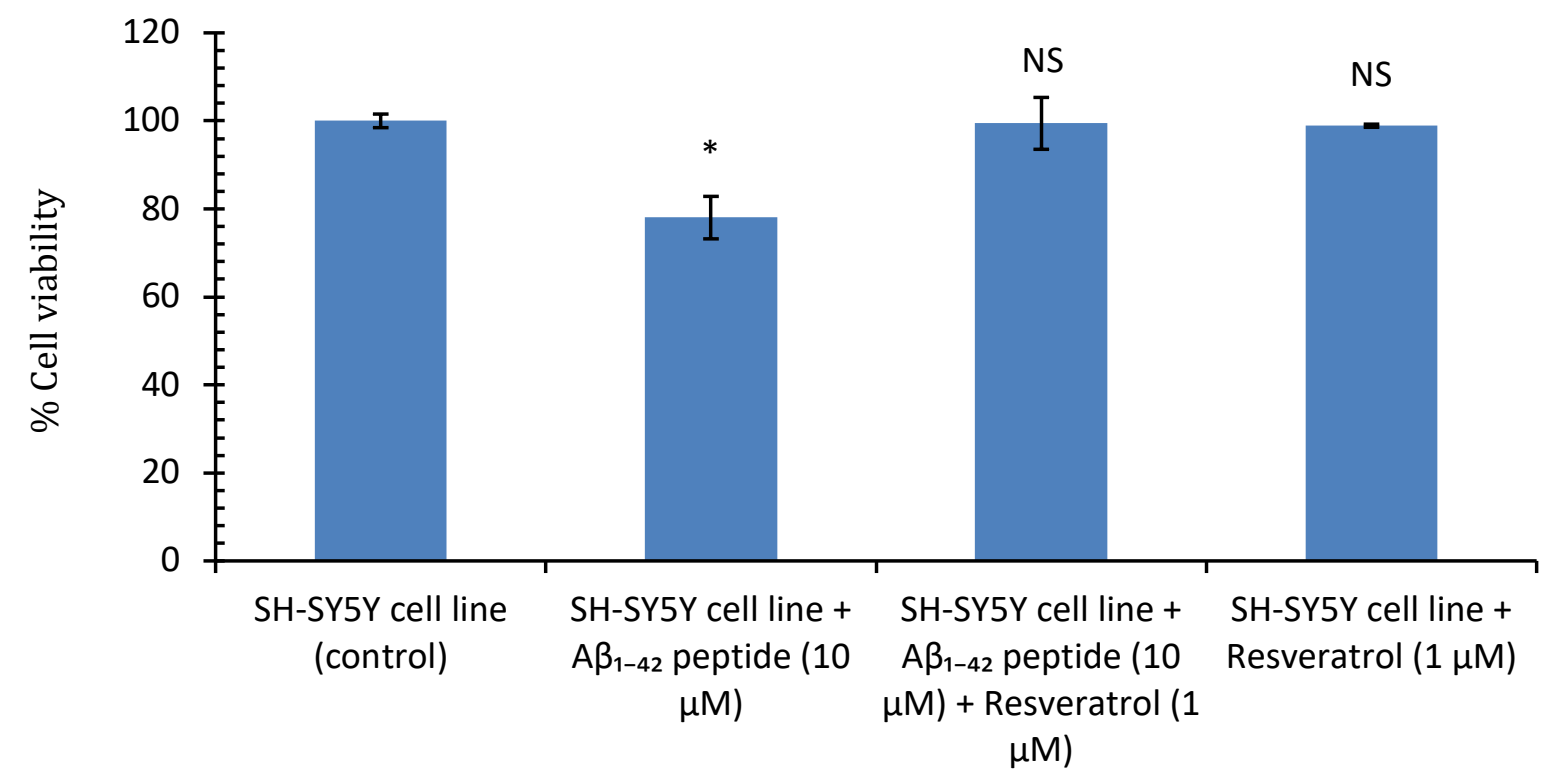

Figure 6. Effect of $A \beta_{1-42}$ peptide and resveratrol on SH-SY5Y cell viability. SH-SY5Y cells in $100 \mu 1$ growth medium were plated into 96 -well plates at a density of $1.5 \times 10^{4}$ cells/well in 96-well plates and left to adhere overnight at $37{ }^{\circ} \mathrm{C}$ in $5 \% \mathrm{CO}_{2}$. Cells were then incubated with $100 \mu$ l growth medium containing either $10 \mu \mathrm{M} \mathrm{A} \beta_{1-42}$ peptide, $1 \mu \mathrm{M}$ resveratrol or $10 \mu \mathrm{M} \mathrm{A} \beta_{1-42}$ peptide and $1 \mu \mathrm{M}$ resveratrol combined for $48 \mathrm{~h}$ at $37{ }^{\circ} \mathrm{C}$ and $5 \% \mathrm{CO}_{2}$. MTT solution $\left(25 \mu 1,5 \mathrm{mg} \cdot \mathrm{ml}^{-1}\right)$ was then added to each well and cells incubated for a further $4.5 \mathrm{~h}$. The growth medium was then removed, cell monolayers washed three times with PBS and $100 \mu$ of $50 \% N, N$-dimethyl-formamide and $20 \%$ SDS (pH 4.8 ) added to each well. Plates were incubated overnight at $37{ }^{\circ} \mathrm{C}$ and the absorbance measured at a test wavelength of $570 \mathrm{~nm}$ and a reference wavelength of $655 \mathrm{~nm}$ using a Polar Star Omega plate reader. Data were analysed using Student's t-test and are expressed as mean \pm standard deviation of four independent experiments, each containing five replicates. $* \mathrm{P}<0.01$ and $\mathrm{NS}=$ not significant.

\section{Conclusions}

We report a novel mechanism by which treatment of $A \beta_{1-42}$ peptide with the polyphenol resveratrol caused fragmentation and prevented $\mathrm{A} \beta_{1-42}$ peptide-mediated toxicity towards SHSY5Y cells. The sites of cleavage in the $A \beta_{1-42}$ peptide are identified between Arg5 and His6 and between Val24 and Gly25. The finding that resveratrol cleaves $A \beta_{1-42}$ peptide into fragments, preventing peptide aggregation, is of interest and of potential application to the treatment of Alzheimer's disease. 
Whilst the current study provides evidence for resveratrol-mediated fragmentation of $\mathrm{A} \beta_{1-42}$ peptide, the polyphenol and its derivatives also demonstrate additional antiamyloidogenic properties. Cleavage of amyloid precursor protein (APP) by $\beta$-secretase (BACE1) results in production of $\mathrm{A} \beta_{1-42}$ peptide. Choi et. al,. (2011) report oligomeric resveratrol significantly inhibited $\beta$-secretase activity (Choi et al., 2011) and Koukoulitsa et. al. (2016) demonstrated the polyphenol also inhibited $\beta$-secretase (Koukoulitsa et al., 2016). Furthermore, a recent study by Chen et. al,. (2019) demonstrated resveratrol reduced expression of APP and its cleavage products in a transgenic mouse model (Chen et al., 2019), however, to date, no studies report resveratrol-mediated fragmentation of holo-APP. Taken together, such findings suggest a multimodal mechanism by which resveratrol potentially influences $A \beta_{1-42}$ peptide levels in the brain.

\section{Acknowledgment}

This work was funded by the Iraqi Ministry of Higher Education and Scientific Research and the University of Manchester. We thank Dr. Steven Marsden (Manchester Institute of Biotechnology) for help with AFM. We thank Dr. Zubida Al-Majdoub, Dr. Jill Barber and Mr. Gareth Smith (School of Chemistry, University of Manchester) for assistance with mass spectroscopy. 


\section{References:}

Abe, K. \& Matsuki, N. 2000. Measurement of cellular 3-(4,5-dimethylthiazol-2-yl)-2,5diphenyltetrazolium bromide (MTT) reduction activity and lactate dehydrogenase release using MTT. Neurosci Res, 38(4), 325-9.

Aggarwal, B. B., Bhardwaj, A., Aggarwal, R. S., Seeram, N. P., Shishodia, S. \& Takada, Y. 2004. Role of resveratrol in prevention and therapy of cancer: preclinical and clinical studies. Anticancer Res, 24(5A), 2783-840.

Attanasio, F., Convertino, M., Magno, A., Caflisch, A., Corazza, A., Haridas, H., Esposito, G., Cataldo, S., Pignataro, B., Milardi, D. \& Rizzarelli, E. 2013. Carnosine inhibits Abeta(42) aggregation by perturbing the H-bond network in and around the central hydrophobic cluster. ChemBioChem, 14(5), 583-92.

Barrow, C. J., Yasuda, A., Kenny, P. T. \& Zagorski, M. G. 1992. Solution conformations and aggregational properties of synthetic amyloid beta-peptides of Alzheimer's disease. Analysis of circular dichroism spectra. J Mol Biol, 225(4), 1075-93.

Bartolini, M., Bertucci, C., Bolognesi, M. L., Cavalli, A., Melchiorre, C. \& Andrisano, V. 2007. Insight into the kinetic of amyloid beta (1-42) peptide self-aggregation: elucidation of inhibitors' mechanism of action. ChemBioChem, 8(17), 2152-61.

Baur, J. A. \& Sinclair, D. A. 2006. Therapeutic potential of resveratrol: the in vivo evidence. Nat Rev Drug Discov, 5(6), 493-506.

Belguendouz, L., Fremont, L. \& Linard, A. 1997. Resveratrol inhibits metal ion-dependent and independent peroxidation of porcine low-density lipoproteins. Biochemical Pharmacology, 53(9), 1347-1355.

Bhushan, I., Kour, M., Kour, G., Gupta, S., Sharma, S. \& Yadav, A. 2018. Alzheimer's disease: Causes $\&$ treatment-A review. Annals of Biotechnology, 1(1-8.

Bohrmann, B., Baumann, K., Benz, J., Gerber, F., Huber, W., Knoflach, F., Messer, J., Oroszlan, K., Rauchenberger, R., Richter, W. F., Rothe, C., Urban, M., Bardroff, M., Winter, M., Nordstedt, C. \& Loetscher, H. 2012. Gantenerumab: A novel human anti-A $\beta$ antibody demonstrates sustained cerebral amyloid- $\beta$ binding and elicits cell-mediated removal of human amyloid- $\beta$. Journal of Alzheimer's Disease, 28(1), 49-69.

Chen, Y., Shi, G. W., Liang, Z. M., Sheng, S. Y., Shi, Y. S., Peng, L., Wang, Y. P., Wang, F. \& Zhang, X. M. 2019. Resveratrol improves cognition and decreases amyloid plaque formation in Tg6799 mice. Mol Med Rep, 19(5), 3783-3790. 
Choi, C. W., Choi, Y. H., Cha, M. R., Kim, Y. S., Yon, G. H., Hong, K. S., Park, W. K., Kim, Y. H. \& Ryu, S. Y. 2011. In vitro BACE-1 inhibitory activity of resveratrol oligomers from the seed extract of Paeonia lactiflora. Planta Med, 77(4), 374-6.

Cohen, T., Frydman-Marom, A., Rechter, M. \& Gazit, E. 2006. Inhibition of amyloid fibril formation and cytotoxicity by hydroxyindole derivatives. Biochemistry, 45(15), 4727-35.

Coskuner, O. \& Wise-Scira, O. 2013. Arginine and Disordered Amyloid- $\beta$ Peptide Structures: Molecular Level Insights into the Toxicity in Alzheimer's Disease. ACS Chemical Neuroscience, 4(12), 1549-1558.

El-Agnaf, O. M., Jakes, R., Curran, M. D., Middleton, D., Ingenito, R., Bianchi, E., Pessi, A., Neill, D. $\&$ Wallace, A. 1998. Aggregates from mutant and wild-type alpha-synuclein proteins and NAC peptide induce apoptotic cell death in human neuroblastoma cells by formation of beta-sheet and amyloid-like filaments. FEBS Lett, 440(1-2), 71-5.

Feng, Y., Wang, X. P., Yang, S. G., Wang, Y. J., Zhang, X., Du, X. T., Sun, X. X., Zhao, M., Huang, L. \& Liu, R. T. 2009. Resveratrol inhibits beta-amyloid oligomeric cytotoxicity but does not prevent oligomer formation. Neurotoxicology, 30(6), 986-95.

Fiala, M. \& Veerhuis, R. 2010. Biomarkers of inflammation and amyloid- $\beta$ phagocytosis in patients at risk of Alzheimer disease. Experimental Gerontology, 45(1), 57-63.

Fu, Z., Aucoin, D., Ahmed, M., Ziliox, M., Van Nostrand, W. E. \& Smith, S. O. 2014. Capping of abeta42 oligomers by small molecule inhibitors. Biochemistry, 53(50), 7893-903.

Ge, J.-F., Qiao, J.-P., Qi, C.-C., Wang, C.-W. \& Zhou, J.-N. 2012. The binding of resveratrol to monomer and fibril amyloid beta. Neurochemistry International, 61(7), 1192-1201.

Grasso, G. 2011. The use of mass spectrometry to study amyloid-beta peptides. Mass Spectrom Rev, $30(3), 347-65$.

Grasso, G., Mineo, P., Rizzarelli, E. \& Spoto, G. 2009. MALDI, AP/MALDI and ESI techniques for the MS detection of amyloid $\beta$-peptides. International Journal of Mass Spectrometry, 282(12), 50-55.

Guo, J. P., Yu, S. \& McGeer, P. L. 2010. Simple in vitro assays to identify amyloid-beta aggregation blockers for Alzheimer's disease therapy. J Alzheimers Dis, 19(4), 1359-70.

Hosia, W., Griffiths, W. J. \& Johansson, J. 2005. Hydrolysis of the amyloid beta-peptide (A beta) 1-40 between Asp23-Val24 produces non-aggregating fragments. An electrospray mass spectrometric study. J Mass Spectrom, 40(2), 142-5. 
Kantham, S., Chan, S., McColl, G., Miles, J. A., Veliyath, S. K., Deora, G. S., Dighe, S. N., Khabbazi, S., Parat, M. O. \& Ross, B. P. 2017. Effect of the Biphenyl Neolignan Honokiol on Abeta42Induced Toxicity in Caenorhabditis elegans, Abeta42 Fibrillation, Cholinesterase Activity, DPPH Radicals, and Iron(II) Chelation. ACS Chem Neurosci, 8(9), 1901-1912.

Kapurniotu, A. 2004. Targeting a-Synuclein in Parkinson's Disease. Chemistry \& Biology, 11(11), 1476-1478.

Koukoulitsa, C., Villalonga-Barber, C., Csonka, R., Alexi, X., Leonis, G., Dellis, D., Hamelink, E., Belda, O., Steele, B. R., Micha-Screttas, M., Alexis, M. N., Papadopoulos, M. G. \& Mavromoustakos, T. 2016. Biological and computational evaluation of resveratrol inhibitors against Alzheimer's disease. J Enzyme Inhib Med Chem, 31(1), 67-77.

Kowalewski, T. \& Holtzman, D. M. 1999. In situ atomic force microscopy study of Alzheimer's betaamyloid peptide on different substrates: new insights into mechanism of beta-sheet formation. Proc Natl Acad Sci US A, 96(7), 3688-93.

Lan, J. S., Liu, Y., Hou, J. W., Yang, J., Zhang, X. Y., Zhao, Y., Xie, S. S., Ding, Y. \& Zhang, T. 2018. Design, synthesis and evaluation of resveratrol-indazole hybrids as novel monoamine oxidases inhibitors with amyloid-beta aggregation inhibition. Bioorg Chem, 76(130-139.

Li, S., Jin, M., Koeglsperger, T., Shepardson, N. E., Shankar, G. M. \& Selkoe, D. J. 2011. Soluble A $\beta$ Oligomers Inhibit Long-Term Potentiation through a Mechanism Involving Excessive Activation of Extrasynaptic NR2B-Containing NMDA Receptors. The Journal of Neuroscience, 31(18), 6627-6638.

Lu, C., Guo, Y., Li, J., Yao, M., Liao, Q., Xie, Z. \& Li, X. 2012. Design, synthesis, and evaluation of resveratrol derivatives as Aß1-42 aggregation inhibitors, antioxidants, and neuroprotective agents. Bioorganic \& Medicinal Chemistry Letters, 22(24), 7683-7687.

Lyons, B., Friedrich, M., Raftery, M. \& Truscott, R. 2016. Amyloid Plaque in the Human Brain Can Decompose from A $\beta(1-40 / 1-42)$ by Spontaneous Nonenzymatic Processes. Analytical Chemistry, 88(5), 2675-2684.

McGowan, E., Pickford, F., Kim, J., Onstead, L., Eriksen, J., Yu, C., Skipper, L., Murphy, M. P., Beard, J., Das, P., Jansen, K., DeLucia, M., Lin, W.-L., Dolios, G., Wang, R., Eckman, C. B., Dickson, D. W., Hutton, M., Hardy, J. \& Golde, T. 2005. A $\beta 42$ is essential for parenchymal and vascular amyloid deposition in mice. Neuron, 47(2), 191-199.

Naldi, M., Fiori, J., Pistolozzi, M., Drake, A. F., Bertucci, C., Wu, R., Mlynarczyk, K., Filipek, S., De Simone, A. \& Andrisano, V. 2012. Amyloid beta-peptide 25-35 self-assembly and its inhibition: a model undecapeptide system to gain atomistic and secondary structure details of the Alzheimer's disease process and treatment. ACS Chem Neurosci, 3(11), 952-62. 
Naslund, J., Karlstrom, A. R., Tjernberg, L. O., Schierhorn, A., Terenius, L. \& Nordstedt, C. 1996. High-resolution separation of amyloid beta-peptides: structural variants present in Alzheimer's disease amyloid. J Neurochem, 67(1), 294-301.

Nedumpully-Govindan, P., Kakinen, A., Pilkington, E. H., Davis, T. P., Chun Ke, P. \& Ding, F. 2016. Stabilizing Off-pathway Oligomers by Polyphenol Nanoassemblies for IAPP Aggregation Inhibition. Sci Rep, 6(19463.

Nichols, M. R., Moss, M. A., Reed, D. K., Cratic-McDaniel, S., Hoh, J. H. \& Rosenberry, T. L. 2005. Amyloid-beta protofibrils differ from amyloid-beta aggregates induced in dilute hexafluoroisopropanol in stability and morphology. J Biol Chem, 280(4), 2471-80.

Orre, M., Kamphuis, W., Dooves, S., Kooijman, L., Chan, E. T., Kirk, C. J., Smith, V. D., Koot, S., Mamber, C., Jansen, A. H., Ovaa, H. \& Hol, E. M. 2013. Reactive glia show increased immunoproteasome activity in Alzheimer's disease. Brain, 136(1415-1431.

Ostapchenko, V., Gasset, M. \& Baskakov, I. V. 2012. Atomic force fluorescence microscopy in the characterization of amyloid fibril assembly and oligomeric intermediates. Methods Mol Biol, 849(157-67.

Parbhu, A., Lin, H., Thimm, J. \& Lal, R. 2002. Imaging real-time aggregation of amyloid beta protein (1-42) by atomic force microscopy. Peptides, 23(7), 1265-1270.

Petkova, A. T., Ishii, Y., Balbach, J. J., Antzutkin, O. N., Leapman, R. D., Delaglio, F. \& Tycko, R. 2002. A structural model for Alzheimer's beta -amyloid fibrils based on experimental constraints from solid state NMR. Proc Natl Acad Sci U S A, 99(26), 16742-7.

Phan, H. T. T., Samarat, K., Takamura, Y., Azo-Oussou, A. F., Nakazono, Y. \& Vestergaard, M. C. 2019. Polyphenols Modulate Alzheimer's Amyloid Beta Aggregation in a Structure-Dependent Manner. Nutrients, 11(4).

Puksasook, T., Kimura, S., Tadtong, S., Jiaranaikulwanitch, J., Pratuangdejkul, J., Kitphati, W., Suwanborirux, K., Saito, N. \& Nukoolkarn, V. 2017. Semisynthesis and biological evaluation of prenylated resveratrol derivatives as multi-targeted agents for Alzheimer's disease. $J$ Nat Med, 71(4), 665-682.

Regitz, C., Fitzenberger, E., Mahn, F. L., Dussling, L. M. \& Wenzel, U. 2015. Resveratrol reduces amyloid-beta (Abeta)-induced paralysis through targeting proteostasis in an Alzheimer model of Caenorhabditis elegans. Eur J Nutr.

Reyes Barcelo, A. A., Gonzalez-Velasquez, F. J. \& Moss, M. A. 2009. Soluble aggregates of the amyloid- $\beta$ peptide are trapped by serum albumin to enhance amyloid- $\beta$ activation of endothelial cells. Journal of Biological Engineering, 3( 
Richard, T., Poupard, P., Nassra, M., Papastamoulis, Y., Iglésias, M.-L., Krisa, S., Waffo-Teguo, P., Mérillon, J.-M. \& Monti, J.-P. 2011. Protective effect of $\varepsilon$-viniferin on $\beta$-amyloid peptide aggregation investigated by electrospray ionization mass spectrometry. Bioorganic \& Medicinal Chemistry, 19(10), 3152-3155.

Ross, R. A., Spengler, B. A. \& Biedler, J. L. 1983. Coordinate morphological and biochemical interconversion of human neuroblastoma cells. J Natl Cancer Inst, 71(4), 741-7.

Rudinskiy, N., Fuerer, C., Demurtas, D., Zamorano, S., De Piano, C., Herrmann, A. G., Spires-Jones, T. L., Oeckl, P., Otto, M., Frosch, M. P., Moniatte, M., Hyman, B. T. \& Schmid, A. W. 2016. Amyloid-beta oligomerization is associated with the generation of a typical peptide fragment fingerprint. Alzheimer's \& Dementia, 12(9), 996-1013.

Sako, M., Hosokawa, H., Ito, T. \& Iinuma, M. 2004. Regioselective oxidative coupling of 4hydroxystilbenes: synthesis of resveratrol and epsilon-viniferin (E)-dehydrodimers. $J$ Org Chem, 69(7), 2598-600.

Sales, J. M. \& Resurreccion, A. V. 2014. Resveratrol in peanuts. Crit Rev Food Sci Nutr, 54(6), 73470.

Stine, W. B., Jr., Snyder, S. W., Ladror, U. S., Wade, W. S., Miller, M. F., Perun, T. J., Holzman, T. F. \& Krafft, G. A. 1996. The nanometer-scale structure of amyloid-beta visualized by atomic force microscopy. J Protein Chem, 15(2), 193-203.

Walle, T. 2011. Bioavailability of resveratrol. Ann N Y Acad Sci, 1215(9-15.

Wang, Y., Latshaw, D. C. \& Hall, C. K. 2017. Aggregation of Abeta(17-36) in the Presence of Naturally Occurring Phenolic Inhibitors Using Coarse-Grained Simulations. J Mol Biol, 429(24), 38933908.

Xu, P., Zhang, M., Sheng, R. \& Ma, Y. 2017. Synthesis and biological evaluation of deferiproneresveratrol hybrids as antioxidants, Abeta1-42 aggregation inhibitors and metal-chelating agents for Alzheimer's disease. Eur J Med Chem, 127(174-186.

Zhang, L., Yagnik, G., Peng, Y., Wang, J., Xu, H. H., Hao, Y., Liu, Y. N. \& Zhou, F. 2013. Kinetic studies of inhibition of the amyloid beta (1-42) aggregation using a ferrocene-tagged beta-sheet breaker peptide. Anal Biochem, 434(2), 292-9.

Zhu, M., Rajamani, S., Kaylor, J., Han, S., Zhou, F. \& Fink, A. L. 2004. The flavonoid baicalein inhibits fibrillation of alpha-synuclein and disaggregates existing fibrils. J Biol Chem, 279(26), 2684657.

Zovo, K., Helk, E., Karafin, A., Tougu, V. \& Palumaa, P. 2010. Label-Free High-Throughput Screening Assay for Inhibitors of Alzheimer's Amyloid-beta Peptide Aggregation Based on MALDI MS. Analytical Chemistry, 82(20), 8558-8565. 
(A)
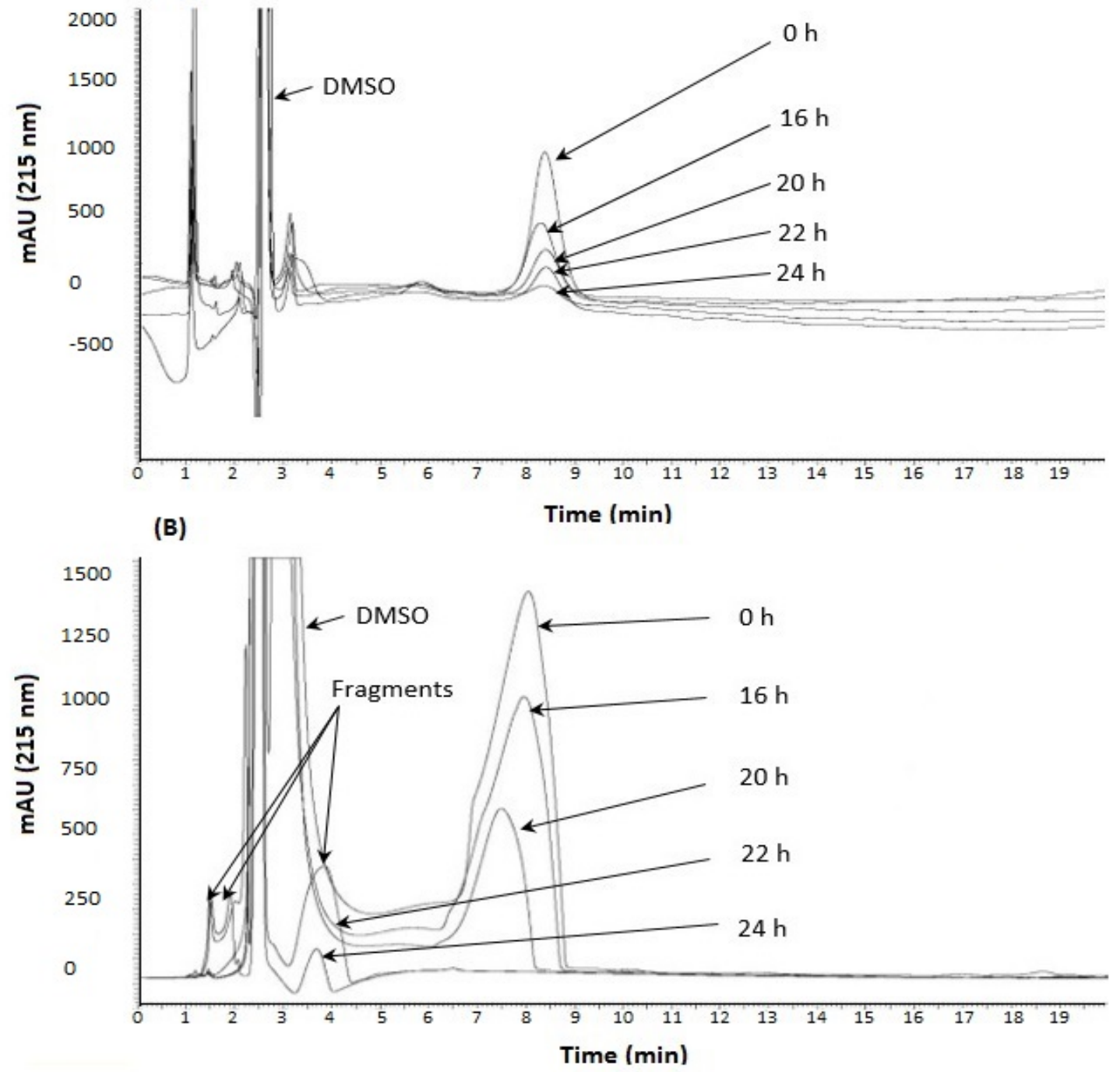

Supplementary Figure 1. Superimposed HPLC analyses of (A) $A \beta_{1-42}$ peptide, $100 \mu \mathrm{M}$, and (B) $\mathrm{A} \beta_{1-42}$ peptide, $100 \mu \mathrm{M}$, incubated with resveratrol at a 1:100 molar ratio over time. 